\title{
Neolithic ceramic spoons - indicators of dietary distinctiveness in the eastern Adriatic Neolithic?
}

\author{
Kristina Horvat \\ Department of Archaeology, University of Zadar, $H R$ \\ k.horvat.zd@gmail.com
}

\begin{abstract}
Among the rich and diverse archaeological finds collected at more than fifty known Neolithic sites in the entire area of the eastern Adriatic and its hinterland, ceramic spoons comprise a group of very rare and almost marginalised items. Only eight examples, discovered in the northern and central Dalmatia region (hinterland of Zadar and Šibenik), at open-air Neolithic sites known to date to the Middle and Late Neolithic. Based on current research and in accordance with the available archaeobotanical and zooarchaeological data from Neolithic sites in the eastern Adriatic region, this paper poses a question about the connection of ceramic spoons with the dietary habits of Neolithic communities in the eastern Adriatic.
\end{abstract}

IZVLEČEK - Keramične žlice predstavljajo skupino redkih in celo marginaliziranih predmetov med drugimi bolj bogatimi in raznolikimi arheološkimi najdbami, ki so jih odkrili na več kot petdesetih neolitskih najdiščih na območju vzhodnega Jadrana in v zaledju. Le osem predmetov, ki so jih odkrili na najdiščih na prostem $v$ severni in osrednji Dalmaciji ( $v$ zaledju Zadra in Šibenika), lahko datiramo $v$ srednji in pozni neolitik. V članku se sprašujemo o povezavah med keramičnimi žlicami in prehranskimi navadami $v$ neolitskih skupnostih v vzhodnem Jadranu. Te povezave gradimo na podatkih iz nedavnih raziskav in v skladu z dosegljivimi arheobotaničnimi in zooarheološkimi podatki za neolitska najdišča $v$ tej regiji.

KEY WORDS - Neolithic; ceramic spoons; dietary habits; eastern Adriatic; Zadar and Šibenik regions

\section{Introduction}

By the mid-20th century, the activities and preoccupations of daily life, as well as different patterns of behaviour conditioned by the objective possibilities and potential of the natural environment were already at the centre of archaeological interest. The life hidden behind rich cultural landscapes and diverse archaeological finds created a need for meaningful and argument-based evaluations of the archaeological record, which hides answers to various questions concerning the social and economic aspects of life of the prehistoric cultures (Novakovic 2008.21-44). At the same time, Neolithic studies also dealt with archaeological artefacts interpreted as the remains of experience arising from the reality in which a community resided. In this context, the archaeological paradigms developed in the mid-20th and during the second half of the $20^{\text {th }}$ century (pro- cessual and experimental archaeology in the1960s, behavioural archaeology in the 1970s and post-processual archaeology in the 1980s) played an important role, along with the general development and intensification of interdisciplinary research, deepening the idea of causal relations between the natural and the cultural, and thus expanding the field of scientific archaeological research work and paving the way for some modern archaeological interests and research concepts. An attempt was made to create a comprehensive archaeological interpretation replaced traditional research approaches and strategies oriented towards stylistic-typological and chronological studies by undertaking research aimed at wider aspects of life, including those related to the eating habits and practices of the Neolithic communities (Rice 1987; Bakić 2001; Sherratt 2002; Urem-Kot- 
sou et al. 2002; Richards et al. 2003; Šoberl et al. 2008; Bonsall et al. 2009; Urem-Kotsou 2011.251; Mlekuž et al. 2012; Budja et al. 2013; Mlekuž et al. 2013).

\section{Life and nutrition in the eastern Adriatic Neo- lithic}

Already in the Early Neolithic, the entire area of the eastern Adriatic, from the Trieste Karst in the north to the Strait of Otranto in the southeast, had become an area of intense interaction with natural resources, which was crucial for the successful development of the Neolithic way of life, as it was based on agriculture and cattle breeding. However, the general acceptance, affirmation and quality of these Neolithic branches, along with hunting, gathering and fishing, were preceded by understanding the naturally heterogeneous environmental conditions in the eastern Adriatic. The alternation of denuded and waterless karst landscapes, sunken karst fields and ridges, limestone plateaus and fertile valleys filled with springs, ravines and underground streams ( $\mathrm{Ma}$ gaš 1998.195) affected all aspects of life, as well as the character and dynamics of cultural development. At the same time, life defined by natural potential and limitations demanded a rational selection of narrow spatial environmental units and a respectful attitude to local resources, which have very often been the main factors in socio-economic development. The capacity to adapt to objective environmental factors (soil, climate, relief etc.) as important existential guidelines reached its full expression in spatial context, starting from the micro-locations of individual settlements to wider spatial patterns of settlement. In this way, settlements became the main centres of interaction between the environment and well-organised Neolithic communities, which attempted to bring all their life preoccupations into the closest contact possible with the available natural resources.

This view is supported by Neolithic sites on the eastern Adriatic divided into three main spatial and settlement clusters based on distribution and density (Fig. 1). In the northern unit, located on the coastal part of Istria and the Kvarner islands, both open-air and cave sites are represented (Zlatunic 2004.26-38). In the second cluster, located in the regions of Zadar and Šibenik, open-air sites are predominate (Batovic 1979. 491, 576), while only cave sites located on the southern Adriatic islands are represented in the third cluster (Marijanovic 2003.111). Significant differences between these spatial units are evident in terms of economic strategies, which clearly follow the natural and geographic variability of the eastern Adriatic landscape. Conditions for the development of cattle breeding were certainly better for communities located in the dynamic karst relief of the northern and southern part of the eastern Adriatic (Brusic 2008.63-64), while the central Zadar and Šibenik regions, still renowned for their large fertile areas, offered the best conditions for agriculture (Magaš 1998.235; Faričić, Marelić 2014).

In view of these differences, undoubtedly conditioned by the causal relationship between the Neolithic communities and the natural basis of the eastern Adriatic, the focus of this paper is on the aforementioned central spatial and settlement unit, which includes the Zadar and Šibenik regions. It is a fertile and area in northern and central Dalmatia, which, owing to its natural position and rich economic potential, has remained an important centre of the diverse cultural, historical and economic development of the eastern Adriatic (Magaš 2013.52-56).

In a broader geographical context, the wider hinterland of Zadar lies in the Ravni Kotari region, which is characterised by parallel forms of Dinaric spreading. Alternating carbonate peaks and fertile valleys filled with the Eocene flysch deposits form the ba-

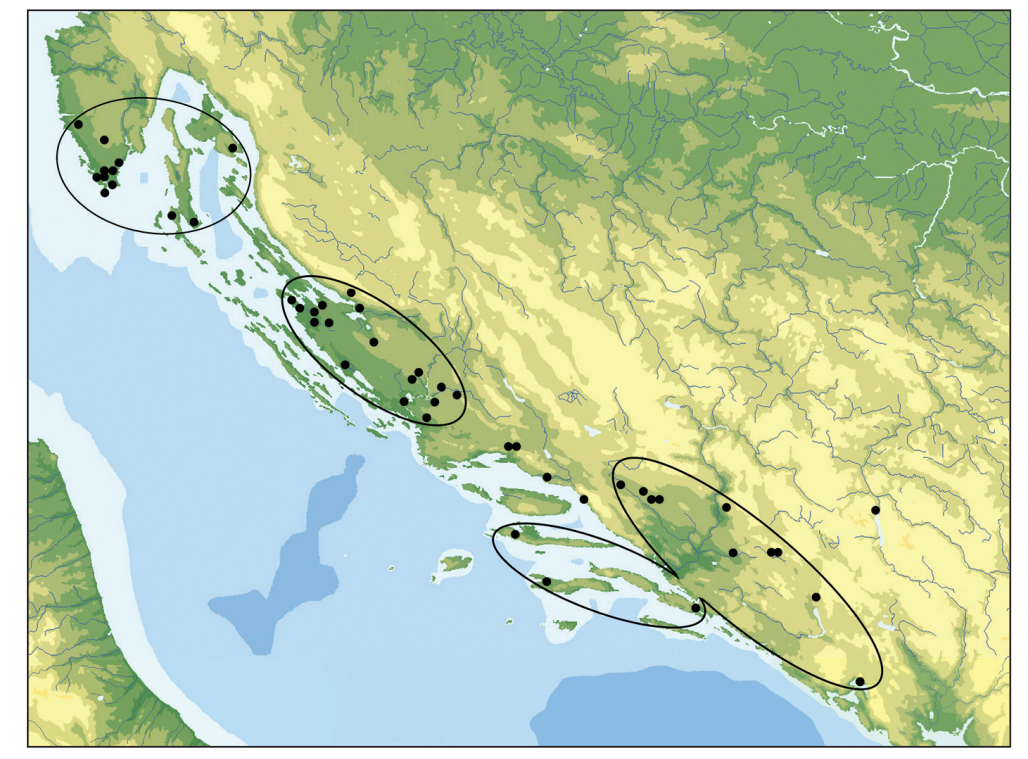

Fig. 1. Spatial-settlement clusters of the Neolithic Eastern Adriatic (after Marijanović 2009.Karta 1). 
sis of a terrain which has no discernible limitations on internal communication (Majcen et al. 1973; Magaš 1998.235). Due to the agricultural potential and water-retention capacities, flysch deposits played a crucial role in the historical and geographical development of this region (Suric 2009.28-31), which is still important in economic terms for the Zadar area. The wider Šibenik region is a transitional area from the northern to the central Dalmatian region. Along with flysch glens, there are basins with deposits of lake sediment from the Neogene, karst hills and karst plateaus, giving this area more dynamic relief features (Magaš 1998.244).

Considering the number, distribution or long duration of the Neolithic settlements in the wider Zadar and Šibenik regions (Fig. 1), we come to the conclusion that it was a very favourable spatial and environmental environment. The fact that its natural resources not only attracted, but also permanently satisfied the subsistence and activities of the Neolithic inhabitants is confirmed by the Neolithic settlements which have been found only a few kilometres apart. Alongside high population density, it is important to emphasise that their stratification testifies to long and very often continuous lives through several periods of the Neolithic (Batovic 1979.579582; Brusić 2008.33-34; Marijanović 2012. 7; Čondic 2012/2013). The constancy of tradition in terms of the retention of the same micro-location for a long period can be considered as a reliable indicator of the balance and stability of life based on various suitable micro-locations, but also evidence of a fairly uniform way of life and economic strategy, which did not require a change from established spatial patterns. From the Early to the Late Neolithic, almost identical micro-locations in the region in northern and central Dalmatia were selected on the periphery of large areas of arable and fertile land close to springs (Batovic 1979.525). As crucial resource and one of the most important determinants in the development of all forms of productive economy, water had a very important role in northern Dalmatia throughout the Neolithic, as confirmed by previously discovered Neoli- thic sites, usually located near watercourses (Batović 1962.32; 1990.32; Korošec 1958.124; Brusić 2008.13; Marijanović 2003a).

To what extent did the consistency of the way of life adapted to the environmental characteristics affect the nutrition of the Neolithic inhabitants of northern and central Dalmatia? Are there any indications of local particularities associated with strictly regional resources in this context? These are issues which have not received major attention (Miracle, Pugsley 2006.313-329; Moor et al. $2007 b$. 30-32; Marijanovic 2009.48-53). However, the discovery of exceptionally rare ceramic spoons during recent archaeological research conducted at sites at Benkovac, Pokrovnik and Velištak has opened new perspectives on this theme.

The Neolithic site at Barice in Benkovac is definitely among the most important archaeological sites in northern Dalmatia. It is a large settlement complex located along the periphery of the modern town of Benkovac, where Early and Middle Neolithic settlements were identified on the basis of archaeological finds and small-scale trial excavations (Batovic 1990.28; Marijanović 2012). Judging from the finds, the settlement may also have seen a Late Neolithic phase (Hvar culture). ${ }^{1}$ Systematic archaeological excavations were carried out in $2012^{2}$ in the central part of the complex, which can be attributed to the Middle Neolithic, or the Danilo culture. Several successive dwelling horizons with well-defined dwellings were found, as well as rich and diverse archaeological finds, including a ceramic spoon ( $V u$ jević, Horvat 2012.44).

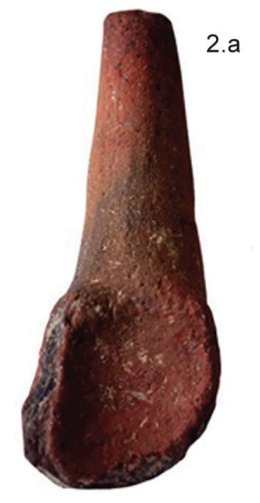

Fig. 2. Ceramic spoons from Barice (Benkovac) and Pokrovnik (foto D. Vujević, S. Govorčin).

1 The information was found in the documentation of the Regional Museum in Benkovac. I would like to thank colleague Marin Curković, director and curator of the museum, for allowing me to see the documentation.

2 The excavations were led by Prof. Branislav Marijanović within the research project Early prehistoric periods in the eastern Adriatic region, as part of students' field practice at the Department of Archaeology, University of Zadar. 
The spoon was found in the north-western corner of a compact research area of $255 \mathrm{~m}^{2}$ in the contact layer between the intact Neolithic layers and upper layers destroyed by lengthy agricultural activities (ploughing). This is clayey and loamy soil under which a segment of floor was
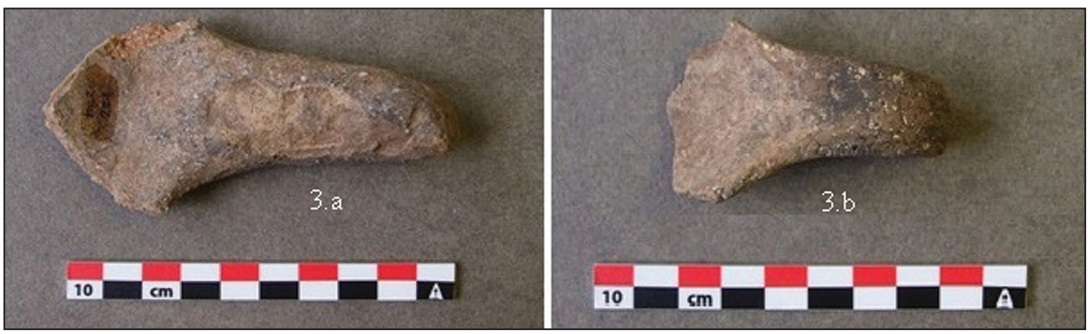

Fig. 3. Ceramic spoons from Pokrovnik and Velištak (foto E. Podrug).

defined with the remains of a small fireplace. The cylindrical handle is fully preserved, while the ends of the concave part are broken off (Fig. 2.a). The technological characteristics of the spoon correspond to the category of coarse Danilo pottery made of purified clay with inclusions of crystalline limestone and small stones (Vujević, Horvat 2012.42).

A similar but finer ceramic spoon was found in 2013 at the Pokrovnik - Copića njive site in the hinterland of Šibenik. It is the Early and Middle Neolithic site (Brusić 2008; Moore et al. 2007a; 2007b) at which the last research campaign was conducted by the Department of Archaeology, University of Zadar. 3 The research in 2013 encompassed the eastern segment of the settlement area (total of $100 \mathrm{~m}^{2}$ ) where only layers of the Danilo culture, i.e. Middle Neolithic were found. Immediately under the humus layer, at a depth of $30 \mathrm{~cm}$, parent rock with a channel $20-30 \mathrm{~cm}$ deep filled with small amorphous rocks was found. A ceramic spoon was singled out among the rich ceramic finds with a fully preserved handle and a concave part with broken ends (Fig. 2.b). The walls of the spoon are finely made, while the fabric corresponds to the other ceramic repertory of coarse Danilo pottery made of clay with a small amount of inclusions (Vujević, Horvat 2016).

The same site produced another ceramic spoon during the first excavations in 1979 (Brusić 2008.T. $L X X I X, 9)$. It was found in the north-eastern part of the excavated area, in a small trial trench $\left(25 \mathrm{~m}^{2}\right)$ which contained Early and Middle Neolithic layers in which the bedrock was reached at a depth of as much as $210 \mathrm{~cm}$. The spoon was found in the cultural of the Middle Neolithic layer at $30-45 \mathrm{~cm}$; this was an

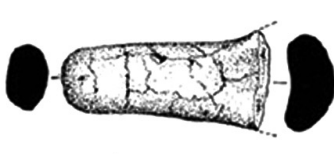

4.a intact Neolithic layer with the remains of dwellings (Brusic 2008.49). The handle of the spoon is fully preserved, while most of the concave portion is missing (Fig. 3.a). It is made of clay with a high percentage of inclusions.

A ceramic spoon was found (Fig. 3.b) at the Late Neolithic site at Čista Mala - Velištak, located in the hinterland of the city of Vodice (Podrug 2010) during the research campaign in $2011^{4}$ in an intact Neolithic cultural layer between humus and bedrock which was not related to some specific archaeological formation. On the basis of radiocarbon dates the layer was ascribed to the first phase of the Hvar culture (4900-4700 BC). Its slightly bent handle was preserved completely, while half of the concave part was missing.

Fragments of three ceramic spoons, hemispherical in shape with thick handles and round section (Fig. 4.b) were found at the Middle Neolithic site of Danilo Bitinj during the first archaeological research projects conducted in the mid-20th century (Korošec 1959). 5 It is interesting that the fabric and production technique of these spoons differ from the other ceramics in which the proportion of inclusions is significantly lower, and the walls are much finer ( $\mathrm{KO}^{-}$ rošec 1958.93).

A ceramic spoon was found among the ceramic finds collected in the 1950s on ploughed fields at the Ba-

Fig. 4. Ceramic spoons from Smilčić and Danilo Bitinj (after Batović 1962.S1. 24.4; Korošec 1959.T. XLVIII, 1-3).

\footnotetext{
3 The research was conducted as part of the research project Early prehistoric periods in the eastern Adriatic region, under the guidance of Prof. Marijanović. The research results have not been published yet.

4 I would like to thank Emil Podrug, curator of the prehistoric collection of Šibenik City Museum, for allowing me to publish the find. 5 Precise information about the context of the find is missing.
} 
rice site in Smilčić (Batović 1962); later excavations at this site revealed Early, Middle and Late Neolithic settlements. This find was the flattened oval handle of a ceramic spoon, with the concave part completely broken off, and can be recognised by a slight expansion (Fig. 4.a). On the basis of the fabric, the spoon was attributed to the fine Danilo pottery (Middle Neolithic) made of well-purified clay (Batović 1962.90).

\section{Discussion}

The spatial distribution and scarcity of the ceramic spoons found in the eastern Adriatic region are indeed most intriguing. How is it possible that among all the rich and diverse archaeological finds collected from more than fifty known Neolithic sites in the entire area of the eastern Adriatic and its hinterland, there have not been more such finds? How can we explain their scarcity outside the limited geographical area of northern and central Dalmatia? Is it just a coincidence, or a true reflection of life and cultural development marked by the emergence of local particularities, in this case materialised in the emergence of ceramic spoons? What caused these particularities and how can we interpret them, given what we know about the region in question? Given that the importance of the environment and its potential is attested in almost every aspect of the life of eastern Adriatic Neolithic communities, from distribution and population density, category and type of settlement, economic strategies, spiritual culture and some other material aspects (Marijanović 2007; Vujevic, Horvat 2013), it seems that answers to these questions should be sought in that direction.

The continuing causal relationship between the natural and the cultural must have assumed a new meaning in the Neolithic period. Natural conditions became an expression of the socio-economic interests of prudent Neolithic communities (Higgs, VitaFinzi 1972) which tried to exploit natural potential as much as possible. In archaeological terms, the relations between the natural and the cultural are reflected in archaeological finds and indicative archaeological appearances, such as the aforementioned micro-location strategies and correspondence of the economic structure in all three Neolithic phases (Batovic 1979). The study of the direct relationship between economic and settlement aspects with the eating habits of the Neolithic communities discussed in this work on the basis of a few ceramic spoons requires a holistic approach, which implies a consideration of the spatial context in which the spoons were found (geographic-environmental and microlocation) together with the available bioarchaeological information testifying to the survival strategies of Neolithic communities in the eastern Adriatic, i.e. the acquisition of food as a form of adjustment to actual natural conditions.

All the previously known Neolithic ceramic spoons were found in the Neolithic settlement in the Zadar and Šibenik regions (Fig. 5). These are open-air sites which date to the Middle and Late Neolithic. Although in these settlements, structures associated with processing and storing foods, such as grain storage pits have been found (Podrug 2012/2013. $205)$ along with hearths and fireplaces (Moore et al. 2007.17), their connection with spoons has not been established. Possible connections might be considered only in the case of Barice in Benkovac, where a spoon was found in a cultural layer positioned over a Neolithic house with a small fireplace. However, since shallow pits filled with small rocks and ash were found at the same time and determined as hearth remains outside the excavated dwellings (Marijanovic 2012.12), this hypothesis on possible connections between the fireplace and spoon remains speculative. A detailed analysis of bio-archaeological data from inside and outside the dwellings would be helpful, especially in interpreting the

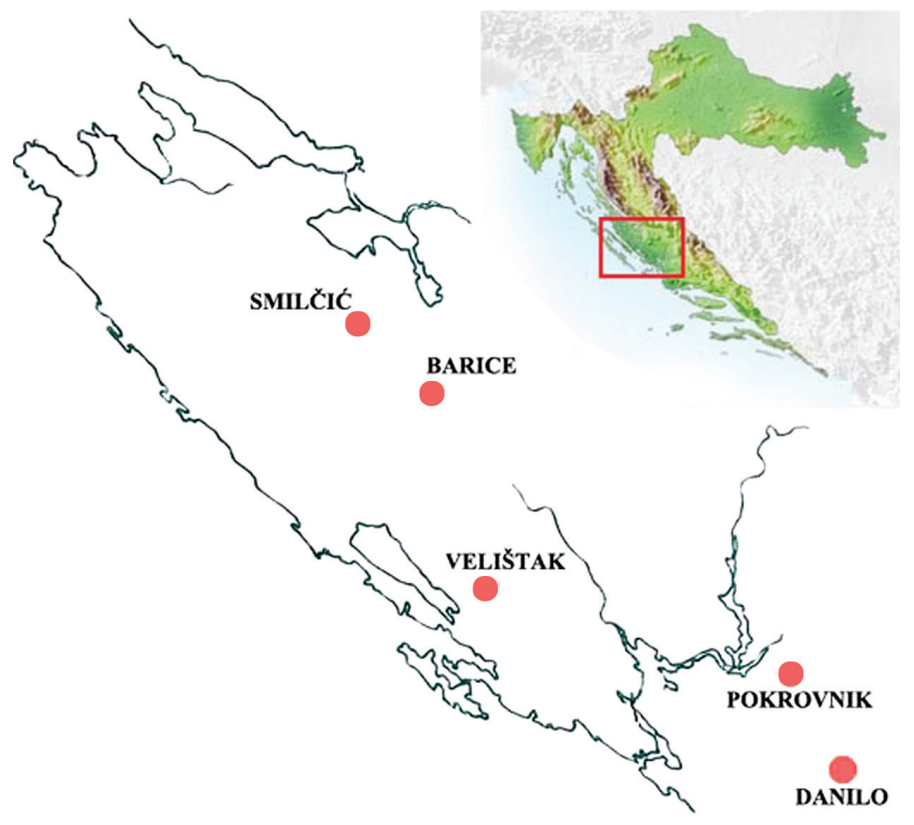

Fig. 5. Position of the Neolithic sites at Barice in Benkovac, Smilčić, Pokrovnik - Copića njive, Danilo Bitinj and Čista Mala - Velištak. 
settlement organisation and understanding the principles of preparation, consumption and storage of food. Recently explored Neolithic sites offer more information on this subject, due to interdisciplinary research which is also aimed at completing the image of the economy of Neolithic communities in the eastern Adriatic.

Excavations in Pokrovnik (Copića njive) have shown that the inhabitants of this Neolithic settlement raised domesticated plants and animals, while game and wild plants were barely represented. Ovicaprids are predominate in the domesticated fauna (82.5\%), and barley (Hordeum sativum), emmer (Triticum dicoccum) and einkorn (Triticum monococcum) predominate among plant remains from the flotation samples (Müller, Karg 1990; Moore et al. 2007b.30). Only minor differences were attested at the Middle Neolithic site of Danilo Bitinj, which is about $10 \mathrm{~km}$ from Pokrovnik. 6 0vicaprids were predominant here as well (79.4\%), and flotation yielded remains of many domesticated and wild plants, with einkorn (Triticum monococcum), hulled barley (Hordeum sativum) and blackberry (Rubus fruticosus) as the most common species (Moore, Menđušić 2004; Moore et al. 2007.19-20). Almost identical information was obtained in the recent analyses of animal remains and carbonised plant remains from the nearby Early Neolithic settlements in Tinj and Crno Vrilo (Huntely 1996; Šoštarić 2009), while maritime fauna were well represented, which is in accordance with its great importance in the diet of the eastern Adriatic Neolithic communities living close to the coast (Marguš et al. 2005; Marijanović 2009.48-49).

On the other hand, paleobotanical analyses of systematically collected samples from the environment of cave sites situated in the karst hinterlands of Istria and the southern, insular area of Dalmatia which lie within the northern and southern Neolithic spatial and settlement cluster (Marijanović 2003) offered different information about the economy of these sites; namely, seeds of domesticated plants have been found only in the layers of the Late Neolithic in Grapčeva cave on the island of Hvar (Borojević et al. 2008.280) and Krčina cave near Klis, where impressions of domesticated wheat grain were found on pottery sherds from the Early Neolithic layers (Müller 1994.64). Paleobotanic finds have not been identified at other excavated sites (Pupićina Peć in Istria and Nakovana Cave on Pelješac) al- though intensive searches have been made (Forenbaher, Kaiser 2000.13-15; Forenbaher, Miracle 2006.491).

Considering the karst basis and total lack of arable land near these cave sites, these data are not surprising. Large amounts of animal remains testify to the predominance of cattle breeding in the cave sites from the Neolithic onwards, and domesticated animals were bred primarily for meat (Miracle, Pugsley 2006.329). This was confirmed by the results of recent analyses of mammal remains from Vela Spila on Korčula, Zemunica Cave in the foothills of northern Mali Mosor (about 35km from Split) and Vela Peć in the western foothills of Učka (Radovic 2011.52, $85,132)$.

Although we have only a few indirect indicators of the spatial varieties of economic/dietary activities of Neolithic communities on the eastern Adriatic, their causality and compatibility with the objective possibilities of the limited spatial and environmental context in the eastern Adriatic is not disputable. Images obtained from the zooarchaeological and archaeobotanical analyses conducted in the area of the central spatial and settlement unit in which ceramic spoons were found is different from the image offered by the analyses of the remains of flora and fauna recorded in the northern and southern Neolithic spatial and settlement units where ceramic spoons were absent. The main difference is in the palaeobotanical material testifying to the cultivation of the Neolithic founder crops in the Zadar and Šibenik regions, i.e. their absence from the cave sites in northern and southern Dalmatia, whose inhabitants engaged exclusively in cattle husbandry. At the present level of exploration, and in accordance with all the aforementioned information, we can assume that the ceramic spoons were related to preparing and consuming cereals, i.e. dietary practices related to the cultivation of the primary domesticates in the regions of northern and central Dalmatia. In accordance with this hypothesis, ceramic spoons can be observed as a kind of indicator of dietary distinctiveness in the Neolithic of the eastern Adriatic, where economic and dietary activities were determined primarily by the natural conditions.

Finally, there is the question of the practical use of ceramic spoons. Judging from the small handle, good condition of the walls and lack of traces of burning,

6 The research was carried out within an international cooperation project of Šibenik City Museum, Drniš City Museum and Rochester Institute of Technology (USA). 
it seems they were not exposed to fire directly, i.e. that they were not used in the cooking process. Some bone spatulae (Bačkalov 1979.24) shaped in a similar way (Fig. 6.d) which were usually used for stirring (Vujević 2009. 96) suggest a similar function for the eastern Adriatic ceramic spoons, particularly if we consider the only slight concavity in the upper part of the spoon, which would make scooping up some form of liquid meal almost impossible. In the same context, recent analyses of pottery typology and lipid residues conducted on Neolithic and Eneolithic pottery from Ajdovska jama, Mala Triglavca and Moverna vas in Slovenia are interesting. They show that some vessel types can be linked to specific foodstuffs or food preparation techniques (Šoberl et al. 2014). Among various types of ceramic shapes, the analysis involved ceramic ladles from the Moverna vas settlement (Fig. 6.e); the organic residue analysis suggests they were used with fatty foods (ruminant adipose fat) (Šoberl et al. 2014.App. 2: sample 155MV), so it can be linked to scooping or stirring, i.e. actions beyond just storing fatty foodstuffs. To determine the function of ceramic spoons, it is also interesting to emphasise that ceramic spoons found at other Neolithic sites, such as those from continental Croatia (Homen 1990.61; Minichreiter, Marković 2009. 34; Marković 2012.61), Hungary (Fig. 6.a-b) (Horváth, Kalicz 2006.60; Regeny 2006.74), Slovenia (Fig. 6.c) (Kramberger 2014) or Slovakia (MüllerKarpe 1968.Tafel 208.13-17) usually have larger concavities and holes for attaching a (wooden?) handle. In contrast, all the examples from northern and central Dalmatia have small clay handles, with no evidence to indicate an additional extension handle.

\section{Conclusion}

Among the diverse range of shapes used for thousands of years in the preparation, serving and eating of different types of food, spoons have proved to be one of the most perfect tools. Their simple design, which has not changed much through history, could be used in a variety of dietary activities, for various food types and ways of preparing food. The function of the ceramic spoons found in the Neoli-

d
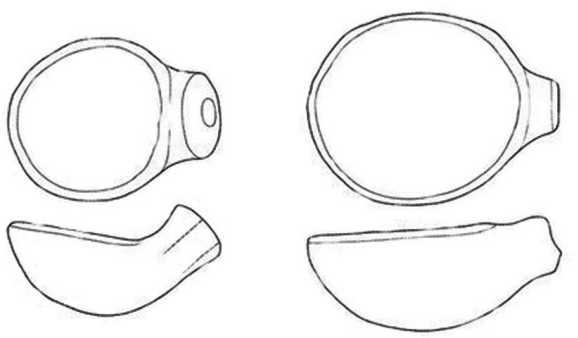

b
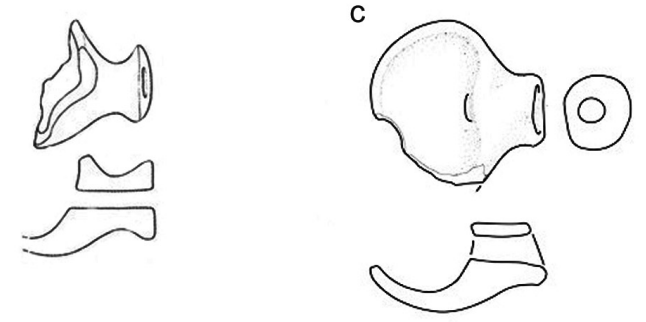

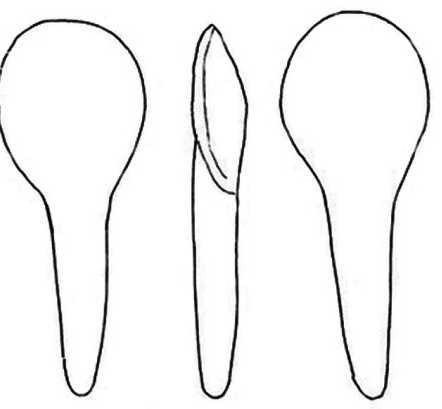

e

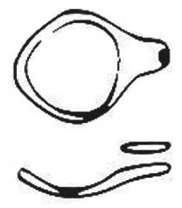

\section{.}

Fig. 6. Ceramic spoons and bone spatulae: a: Nagykanizsa (af(a) Kalicz 2006.60); b: Kaposvár-Gyertyános (after Regeny 2006.74); c: Zgodnje Radvanje (after Kramberger 2014.PI. 8.141); e: Moverna vas (after Šoberl et al. 2014.Fig. 3); d: bone spatulae from Starčevo (after Bačkalov 1979.24).

thic settlements in Benkovac, Pokrovnik, Velištak, Danilo and Smilčić cannot be determined with certainty without a precise biochemical analysis and further research, which would help to define the actual function of at least some of the specimens.

Until possible new finds of ceramic spoons are unearthed in some clearly defined settlement contexts unquestionably related to the preparation or consumption of food, and on the basis of examples of ceramic spoons found in a rather small geographic region of the eastern Adriatic inhabited by Neolithic communities engaged in farming 'primary domesticates' (Batović 1979.553; Šoštarić 2009.51), we may consider a possible link between the ceramic spoons and nutrition related to cereals. Will the new research in the eastern Adriatic and its hinterland confirm that link or provide some other information on the eating habits of the Neolithic communities of this region? Are ceramic spoons associated exclusively with open-air sites, or can they be expected in the cave sites, as is the case in Slovenia or 
Italy, where ceramic spoons were found at open-air sites (Šavel 2006.90; Kramberger 2010.312) and at cave sites (Gilli, Montagnari Kokelj 1996.88) which had fully developed animal husbandry with agriculture, i.e. a mixed economy producing milk and processed milk, meat animal products, freshwater fish and various plants (Budja et al. 2013; $\breve{\text { So- }}$ berl et al. 2014)? In future investigations, more at- tention should be paid to the dietary habits of the Neolithic communities of the eastern Adriatic. In this regard, emphasis should be placed on chemical analyses of organic residues on pottery, which have recently improved our knowledge of the practical use of various vessel forms, food preparation techniques and the diversity of food consumed in the past.

\section{References}

Bačkalov A. 1979. Predmeti od kosti i roga u preneolitu i neolitu Srbije. Savez arheoloških društava Jugoslavije Beograd. Beograd.

Bakić J. 2001. Prehrana korisnika Vele špilje u svjetlu prehrane stanovnika u neolitiku. Izdanja Hrvatskog arheološkog društva 20: 125-131.

Batović Š. 1962. Neolitsko naselje u Smilčiću. Diadora 2: 31-107.

1979. Jadranska zona. In A. Benac (ed.), Praistorija jugoslavenskih zemalja II. Neolit. Akademija Nauka i Umjetnosti Bosne i Hercegovine, Centar za Balkanološka Ispitivanja. Sarajevo: 473-634.

1990. Benkovački kraj u prapovijesti. Radovi Filozofskog fakulteta u Zadru, Razdio povijesnih znanosti 29(16): 5-142.

Bonsall C., Cook G. T., Pickard C., McSweeney K. and Bartosiewicz L. 2009. Dietary trends at the Mesolithic-Neolithic transition in North-west Europe. In P. Crombé, M. Van Strydonck, J. Sergan, M. Boudin and M. Bats (eds.), Chronology and Evolution within the Mesolithic of NorthWest Europe. Cambridge Scholars Publishing. Newcastle upon Tyne: 539-562.

Borojević K., Forenbaher S., Kaiser T. and Berna F. 2008. Plant Use at Grapčeva Cave and in the Eastern Adriatic Neolithic. Journal of Field Archaeology 33(3): 279-303.

Brusić Z. 2008. Pokrovnik - naselje iz neolitika. Muzej grada Šibenika. Šibenik.

Budja M., Ogrinc N., Žibrat Gašparič A., Potočnik D., Žigon D. and Mlekuž D. 2013. Transition to farming - transition to milk culture a case study from Mala Triglavca, Slovenia. Documenta Praehistorica 40: 97-117.

Čondić N. 2012/2013. Neolitičko nalazište u Sikovu. Diadora 26/27: 93-116.
Faričić J., Marelić T. 2014. Prirodno-geografske osnove razvitka Zadarske županije. In J. Faričić (ed.), Potencijali društveno-ekonomskog razvitka Zadarske županije. Sveučilište u Zadru. Zadar: 44-61.

Forenbaher S., Kaiser T. 2000. Grapčeva spilja i apsolutno datiranje istočnojadranskog neolitika. Vjesnik za arheologiju i historiju dalmatinsku 92: 9-34.

Forenbaher S., Miracle T. 2006. Pupicina Cave and the Spread of Farming in the Eastern Adriatic. In P. T. Miracle and S. Forenbaher (eds.), Prehistoric Herders of Northern Istria: The Archaeology of Pupicina Cave, Vol. 1. Monografije i katalozi 14. Arheološki muzej Istre. Pula: 429-446.

Gilli E., Montagnari Kokelj E. 1996. La Grotta degli Zingari nel Carso Triestino (materiali degli scavi 1961-1965). Atti Società Preistoria Protostoria Friuli-Venezia Giulia IX: 63-126.

Higgs E. S., Vita-Finzi C. 1972. Prehistoric economies: a territorial approach. In E. S. Higgs (ed.), Papers in economic Prehistory. Cambrige University Press. Cambrige: $27-36$.

Homen Z. 1990. Lokaliteti lasinjske kulture na križevačkom području. Arheološka istraživanja u Podravini i kalničko - bilogorskoj regiji. Izdanja Hrvatskog arheološkog društva 14: 51-68.

Horváth L., Kalicz N. 2006. Siedlungsfunde der spätesten Phase der Lengyel-Kultur bei Nagykanizsa (sudwestungarn) (die Letzten zwei drittel des 5 . jahrtausends v. chr., kalibriert). In A. Tomaž (ed.), Od Sopota do Lengyela Prispevki o kamenodobnih in bakrenodobnih kulturah med Savo in Donavo. Annales Mediterranea. Univerzitetna založba Annales UP ZRS. Koper: 53-66.

Huntely J. 1996. The plant remines. In J. Champan, R. Shiel and Š. Batović (eds.), The Changing Face of Dalmatia, Archaeological and Ecological Studies in Mediterranean Landscape. Leicester University Press. London. 
Korošec J. 1958. Neolitska naseobina u Danilu Bitinju. Jugoslavenska akademija znanosti i umjetnosti. Zagreb.

1959. Neolitska naseobina u Danilu Bitinju. Prilozi. Jugoslavenska akademija znanosti i umjetnosti. Zagreb.

Kramberger B. 2010. Zgornje Radvanje, Cluster 10 - a Late Neolithic pit with a structure and smaller pits. Documenta Praehistorica 37: 311-337.

2014. The Neolithic-Eneolithic sequence and pottery assemblages in the fifth millennium BC in north-eastern Slovenia. Documenta Praehistorica 41: 237-282.

Majcen Ž., Korolija B., Sokač B. and Nikler L. 1973. Osnovna geološka karta SRFJ 1:100 000, Tumač za list Zadar L 33-139. Institut za geološka istraživanja Zagreb. Savezni geološki zavod. Beograd.

Magaš D. 1998. Osnove geografije Hrvatske. Filozofski fakultet Zadar. Odsjek za geografiju. Zadar.

2013. Geografija Hrvatske. Sveučilište u Zadru, Odjel za geografiju. Zadar.

Marijanović B. 2003. Geomorfološke osnove naseljavanja jadranskog područja u neolitiku. Histria Antiqua 11: 107-117.

2003a. Višeznačnost vode u životu prapovijesnih zajednica na jadranskome području. Histria Antiqua 10: $45-55$.

2007. Neka pitanja ranog neolitika istočnog Jadrana. Archaeologia Adriatica 1: 7-54.

2009. Crno vrilo I. Sveučilište u Zadru. Zadar.

2012. Barice - naselje danilske kulture u Benkovcu. Archaeologia Adriatica 6: 1-30.

Marguš D., Menđušić M. and Moore A. 2005. Danilo Bitinj - Školjkaši. Obavijesti Hrvatskog arheološkog društva 3: 56-61.

Marković Z. 2012. Novija razmatranja o nekim aspektima sopotske kulture u sjevernoj Hrvatskoj. Prilozi Instituta za arheologiju u Zagrebu 29: 57-70.

Minichreiter K., Marković Z. 2009. Prapovijesno i ranosrednjovjekovno naselje Bentež kod Beketinaca. Prilozi Instituta za arheologiju u Zagrebu 26: 21-44.

Miracle P., Pugsley L. 2006. Ostaci faune kralježnjaka iz Pupićine peći. In P. T. Miracle, S. Forenbaher (eds.), Prehistoric Herders of Northern Istria: The Archaeology of
Pupicina Cave, Vol. 1. Monografije i katalozi 14. Arheološki muzej Istre. Pula: 259-399.

Mlekuž D., Žibrat Gašparič A., Horvat M. and Budja M. 2012. Houses, pots and food: the pottery from Maharski prekop in context. Documenta Praehistorica 39: 325338 .

Mlekuž D., Ogrinc N., Horvat M., Žibrat Gašparič A., Gams Petrišić M. and Budja M. 2013. Pots and food: uses of pottery from Resnikov prekop. Documenta Praehistorica 40: 131-146.

Moore A., Menđušić M. and Smith J. 2007a. Project "Early farming in Dalmatia": Danilo Bitinj 2004-2005. Vjesnik Arheološkog muzeja u Zagrebu 40: 15-24.

Moore A., Menđušić M., Smith J., Podrug E. and Zaninović J. 2007b. Project "Early farming in Dalmatia": Pokrovnik 2006. Vjesnik Arheološkog muzeja u Zagrebu 40: 2534

Müller J., Karg S. 1990. Neolithische Getreidefunde aus Pokrovnik, Dalmatien. Archäologisches Korrespondenzblatt 20: 373-386.

Müller J. 1994. Das ostadriatische Frühneolithikum. Die Impresso-Kultur und die Neolithisierung des Adriaraumes. Prähistorische Archäologie in Südosteuropa 9. Wissenschaftsverlag Volker Spiess. Berlin.

Müller-Karpe H. 1968. Handbuch der Vorgeschichte. Beck. München.

Novaković P. 2008. Arheologija prostora i arheologija krajolika. In Olujić B. (ed.), Povijest u kršu. Naselja i komunikacije u kontekstu veza jadranskog priobalja $i$ unutrašnjosti. Sveučilište u Zagrebu. Filozofski fakultet. Zagreb: $15-54$

Podrug E. 2010. Čista Mala - Velištak: prve tri istraživačke kampanje na nalazištu hvarske kulture. Diadora 24 : $7-25$.

2012/2013. Neolitički nepokretni nalazi na šibenskom području. Diadora 26/27: 185-211.

Radović S. 2011. Ekonomija prvih stočara na istočnom Jadranu: značenje lova $i$ stočarstva u prehrani neolitičkih ljudi. Unpublished PhD thesis. Sveučilište u Zagrebu. Filozofski fakultet. Zagreb.

Regeny J. 2006. Kaposvár-Gyertyános, Die Siedlung der Lengyel Kultur. In A. Tomaž (ed.), Od Sopota do Lengyela - Prispevki o kamenodobnih in bakrenodobnih kulturah med Savo in Donavo. Annales Mediterranea. Univerzitetna založba Annales UP ZRS. Koper: 67-74. 
Rice P. M. 1987. Pottery Analysis. A Sourcebook. University of Chicago Press. Chicago

Richards M. P., Pearson J. A., Molleson T. I., Russell N. and Martin L. 2003. Stable Isotope Evidence of Diet at Neolithic Çatalhöyük, Turkey. Journal of Archaeological Science 30: 67-76.

Sherratt A. 2002. Diet and cuisine: farming and its transformations as reflected in pottery. Documenta Praehistorica 29: 61-71.

Surić M. 2009. Geološke i hirdološke značajke šireg područja lokaliteta. In B. Marijanović (ed.), Crno vrilo 2. Sveučilište u Zadru. Zadar: 27-33.

Šavel I. 2006. Prekmurje v mlajši kameni dobi. In A. Tomaž (ed.), Od Sopota do Lengyela - Prispevki o kamenodobnih in bakrenodobnih kulturah med Savo in Donavo. Annales Mediterranea. Univerzitetna založba Annales UP ZRS. Koper: 89-94.

Šoberl L., Žibrat Gašparić A., Budja M. and Evershed P. R. 2008. Early herding practices revealed through organic residue analysis of pottery from the early Neolithic rock shelter of Mala Triglavca, Slovenia. Documenta Praehistorica 35: 253-260.

Šoberl L., Horvat M., Žibrat Gašparič A., Sraka M, Evershed R. and Budja M. 2014. Neolithic and Eneolithic activities inferred from organic residue analysis of pottery from Mala Triglavca, Moverna vas and Ajdovska jama, Slovenia. Documenta Praehistorica 41: 149-179.
Šoštarić R. 2009. Karbonizirani ostatci žitarica - tragovi poljodjelstva. In B. Marijanović (ed.), Crno vrilo 2. Sveučilište u Zadru. Zadar: 49-52.

Urem-Kotsou D., Kotsakis K. and Stern B. 2002. Defining function in Neolithic ceramics: the example of Makriyalos, Greece. Documenta Praehistorica 29: 109-118.

Urem-Kotsou D. 2011. Noviji pristup u proučavanju keramike. Upotreba posuda $i$ analiza ostataka hrane $u$ neolitičkoj keramici sjeverne Grčke. Panonski prapovijesni osviti. Zbornik radova posvećenih Korneliji Minichreiter uz 65. obljetnicu života. Institut za arheologiju. Zagreb: $247-266$.

Vujević D. 2009. Predmeti od kosti roga. In B. Marijanović (ed.), Crno vrilo 2. Sveučilište u Zadru. Zadar: 89-123.

Vujević D., Horvat. K. 2012. Kulturna slika danilskog naselja na Baricama. Archaeologia Adriatica 6: 31-65.

2013. Neolitičke keramičke pločice. Archaeologia Adriatica 7: 95-112.

2016. Nova istraživanja neolitičkog nalazišta u Pokrovniku (in press).

Moore A., Menđušić M. 2004. The development of farming in Adriatic basin: new research at Danilo in Dalmatia. Obavijesti Hrvatskog arheološkog društva 36: 33-34.

Zlatunić R. 2004 Arheološka interpretacija i rekonstrukcija načina života u neolitičkom razdoblju Istre. Histria Archaeologica 33(2002): 5-141. 